\title{
Effect of Profitability and Size Companies on Tax Avoidance in Manufacturing Companies Listed in Indonesia Stock Exchange
}

Hj. Masnawaty S.

Universitas Negeri Makassar

\section{Abstract}

This research aims to determine the effect of profitability and size companies on tax avoidance in companies listed on the Indonesia Stock Exchange. This research uses the dependent variable, namely tax avoidance, and independent variables - profitability and the size of the company. Data collection technique used is documentation. Data analysis technique used is multiple linear regression method. The results showed that the profitability and size companies variables simultaneously affect tax avoidance with a significant value below 0.05 and the adjusted $R$ square value of 0.48 . While partially only profitability variables affect tax avoidance with a significant value below 0.05 .
Corresponding Author:

Hj. Masnawaty S.

masnawaty.s@unm.ac.id

Received: 29 January 2019

Accepted: 27 February 2019

Published: 24 March 2019

Publishing services provided by Knowledge E

(c) Hj. Masnawaty S.. This article is distributed under the terms of the Creative Commons

Attribution License, which permits unrestricted use and redistribution provided that the original author and source are credited.

Selection and Peer-review under the responsibility of the $3 r d$ ICEEBA Conference Committee.

\section{Introduction}

In Indonesia, efforts to maximize revenue through problems. "One of the problems in maximizing tax revenue in Indonesia is the tax avoidance effort, not even a few companies that do tax avoidance" (Setiyono, 2012).

Tax avoidance is an effort to avoid taxation that is done legally and safely for taxpayers because it does not conflict with taxation provisions, where the methods and techniques used tend to exploit weaknesses, while tax evasion is the taxpayer's effort avoiding tax owed illegally by hiding the real situation, efforts to reduce this tax debt are illegal (unlawful).

The research that underlies this research is Wirna's (2014) research which uses three independent variables namely profitability, leverage and corporate governance. Whereas in this study the reduction of corporate governance and leverage variables was added and the company size variable was added.

From the description that has been conveyed before, the researcher is interested in taking the title "The Effect of Company Profitability and Size on Tax Avoidance in 


\section{Manufacturing Companies Listed on the Indonesia Stock Exchange for the 2015-2017 Period."}

\section{Review of Literature}

\subsection{Tax}

Pursuant to Article 1 of Act Number 16 of 2009 concerning General Provisions and Procedures for Taxation, tax is a compulsory contribution to the state owed by an individual or a compelling entity based on the law, by not being rewarded directly and used for state purposes. for the greatest prosperity of the people.

\subsection{Profitability}

According to Sugiyarso and Winarni (2005: 118) "Profitability is the ability of a company to make a profit in relation to the sale of total assets and own capital."

According to Kurniasih and Sari (2013): "Profitability is the ability to generate profits at the level of sales, certain assets and share capital."

\subsection{Company size}

According to Riyanto (2008: 313 ) the size of the company is "the size of the company is seen from the value of equity, sales value or value of assets." Meanwhile, according to Ngadiman and Puspitasari (2014) states that:

Company size is a scale that can classify companies into large and small companies according to various ways such as total assets or total assets of the company, stock market value and number of sales.

\subsection{Tax avoidance}

Tax (tax avoidance) is one of the efforts to minimize the tax burden that is often carried out by companies, because it is still within the framework of the applicable tax regulations. Although tax evasion is legal, the government still does not want it.

According to Pohan (2013) the definition of tax avoidance is: Tax avoidance is a tax avoidance effort that is carried out legally and safely for taxpayers because it does not conflict with taxation provisions, where the methods and techniques used tend to utilize 
the weaknesses (gray areas) contained in the tax laws and regulations themselves to reduce the amount of tax owed

\section{Research Methods}

1. Research variable

Variables become something important in a study because it can be a reference and focus of a research. There are three variables in this study, namely Profitability, Company Size and Tax Avoidance.

\section{Research design}

This research is a quantitative research which is a type of research intended to explain phenomena using numerical data, then analyzed which generally uses statistics. The data used in this study is secondary data in the form of quantitative data, namely data in the form of numbers or qualitative data that is assumed. The population used in this study are manufacturing companies listed on the Indonesia Stock Exchange. Data collection techniques used in this study were purposive sampling techniques.

\subsection{Operational definition and variable measurement}

\section{Tax avoidance}

The estimation model of tax avoidance measurement in this study uses the Cash Effective Tax Rate (CETR) model which is expected to be able to identify the aggressiveness of corporate tax planning using fixed differences or temporary differences. The tax avoidance formula according to Ngadiman and Puspitasai (2014) is:

$$
\text { CETR }=(\text { Tax Payment }) /(\text { Profit Before Tax })
$$

The greater the CETR indicates the lower level of corporate tax avoidance.

2. Profitability

Measurement of profitability is using Return on Assets (ROA). ROA is a comparison between net income and total assets at the end of the period, which is used as an indicator of the company's ability to generate profits. According to Manahan (2013: 43) ROA can be calculated using the following formula.

ROA = (net income after tax) / (total assets) 


\section{Company Size}

Company size is a tool to measure the size of a company in a manufacturing company listed on the Indonesia Stock Exchange. In this study, the indicator used to measure the level of company size is total assets $=$ In (total assets).

\subsection{Population and sample}

1. Population

The population used in this study are manufacturing companies listed on the Indonesia Stock Exchange (IDX). The population in this study are all manufacturing companies listed on the Indonesia Stock Exchange as many as 142 companies.

\section{Sample}

The selection of samples using purposive method (judgment sampling) with the aim of getting a representative sample according to the criteria Of the 142 companies listed on the Indonesia Stock Exchange that can meet all the predetermined criteria, namely 58 companies. So the sample that can be used in research in 58 companies multiplied in successive years is 174 (attachment).

\subsection{Data types and sources}

\section{Data Type}

The type of research that the author uses in this study is quantitative research because this study is presented with numbers. The type of data used is documentary data, namely research data in the form of reports.

\section{Data source}

This study uses secondary data, namely the company's financial data from the company's financial statements obtained from the Indonesia Stock Exchange website www.idx.co.id in 2015-2017, and documentary data obtained by researchers from literature studies and reviewed previous research.

\subsection{Data collection technique}

To obtain the data needed in this study the author uses documentation techniques by looking at the sample company's financial statements. With this technique the author collects corporate financial report data from 2015 to 2017 


\subsection{Data analysis design}

\subsubsection{Multiple linear regression analysis}

Multiple regression analysis is an analysis of the relationship between one dependent variable with two or more independent variables (Arikunto, 2010: 25). So when associated with this research, multiple regression analysis is to identify variables that affect tax avoidance. Multiple Regression Analysis Formulas according to Widarjono (2010: 15) are as follows:

$$
Y=\beta 0+\beta 1 X 1+\beta 2 X 2
$$

Information:

Y: Tax avoidance (CETR)

X1: Return on Assets (ROA)

X2: Company Size (UP)

$\beta 0$ : Constants

$\beta 1, \beta 2$, The regression coefficient of each independent variable

\subsubsection{Descriptive statistical analysis}

Descriptive statistics are used to describe and describe variables in this research. Descriptive statistics in research is basically a process of transforming research data in tabulation form so that it is easy to understand and interpret. Tabulation present summary, arrangement or compilation of data in table form and graphics.

\subsubsection{Classic assumption test}

1. Multicollinearity Test

Multicollinearity test aims to test whether the regression model found correlation between independent variables. A good regression model should not have a correlation between the independent variables. If the independent variables correlate, these variables are not orthogonal. An orthogonal variable is an independent variable with a correlation value between fellow independent variables equal to zero (0). Multicollinearity test is done by looking at the tolerance value and Variance Inflation Factor (VIF), with the following decision-making bases: 
(a) If the tolerance value approaches 1 and the VIF value is below 10, then there is no multicollinearity problem.

(b) If the tolerance value is not close to 1 and the VIF value is above 10, then there is a multicollinearity problem.

\section{Heteroscedasticity Test}

Heteroscedasticity test aims to test whether in the regression model there is a residual variance inequality one observation to another observation. If the residual variance from one observation to another is fixed, then it is called homokedastisitas and if different is called heteroscedasticity. According to Ghozali (2011: 105) "A good regression model is homokedasticity or heteroscedasticity does not occur."

Indicators of the presence or absence of heteroscedasticity in this test is that if the significance value is greater than 0.05 the conclusions do not occur heteroscedasticity and if the significance value is smaller than 0.05 the conclusion is heteroscedasticity.

\subsubsection{Hypothesis testing}

\section{Test $f$}

F or simultaneous test is used to prove the validity of hypotheses simultaneously or overall that is to determine the effect of profitability and firm size together or simultaneously on tax avoidance. The calculated $f$ value can be searched by using SPSS version 23 . The test criteria are:

(a) If $p$-value $\leq 0.05$ then $\mathrm{HO}$ is rejected or in other words alternative hypothesis is accepted, meaning that the independent variables affect the dependent variable.

(b) If $p$-value $>0.05$ then $\mathrm{HO}$ is accepted or in other words the alternative hypothesis is rejected, meaning that the independent variables do not affect the dependent variable.

\section{Test $t$}

Used to test whether the independent variable has a partial effect on the dependent variable, then the $t$-test is used using the help of the SPSS program to find the value of $t$-count. Testing criteria are: 
(a) If $p$-value $\leq 0.05$ then $\mathrm{HO}$ is rejected or in other words alternative hypothesis is accepted, meaning that the independent variable partially or individually has a significant influence on the dependent variable.

(b) If $p$-value $>0.05$ then $\mathrm{HO}$ is accepted or in other words the alternative hypothesis is not acceptable, meaning that the independent variables partially or individually do not have a significant influence on the dependent variable.

\subsubsection{Determination coefficient (R2)}

The coefficient of determination (R2) essentially measures how far the ability of the model in explaining the variation of the dependent variable. The value of the coefficient of determination is between zero and one $(0<R 2<1)$.

According to Ghozali (2011: 87):

A small R2 value means that the ability of independent variables in explaining the variation of the dependent variable is very limited. $\mathrm{R} 2$ values that approach one means that the independent variables provide almost all the information needed to predict the variation of the dependent variable.

\section{Discussion}

\subsection{Formed multiple linear regression models}

Based on the test results above, the test results on the multiple regression coefficients produce the following models:

$$
Y=0.515+0.002 X 1-0.008 X 2 .
$$

The explanation is as follows:

(a) 0.515 is a constant value, this constant value indicates that if the profitability and firm size variables do not exist, then the tax avoidance is 0.515 . In other words, tax avoidance is 0.515 before or without the profitability and size of the company.

(b) 0.002 that is the profitability regression coefficient value, this shows that every profitability increases 1 time, then tax avoidance will increase by 0.002 times. In other words, every increase in tax avoidance requires profitability of 0.002. Assuming other variables remain.

(c) -0.008 that is the company size variable coefficient value, this shows that every company size increases 1 time, then tax avoidance will increase by -0.008 times. 
In other words, any increase in tax avoidance requires a company size of -0.008 assuming other variables remain.

\subsection{Descriptive statistics test results}

Descriptive statistical analysis is used to determine the description of the research variables, namely tax avoidance, profitability and firm size in manufacturing companies listed on the Indonesia Stock Exchange (IDX). The values seen from descriptive statistics are the minimum value, maximum, mean (mean), and standard deviation.

Based on the results of descriptive statistical tests obtained as many as 174 observational data derived from this research year with the number of sample companies (58 companies). Descriptive statistical test results can be seen in table 9 below.

TABLE 1: Results of descriptive statistical tests.

\begin{tabular}{l|c|c|c|c|c|}
\hline Variable & Statistics(N) & Maximum & Minimum & Mean & $\begin{array}{c}\text { Standard } \\
\text { deviation }\end{array}$ \\
\hline Profitability & 174 & 0.07 & 120.78 & 10.76 & 14.35 \\
\hline Size companies & 174 & 21.46 & 33.00 & 28.11 & 1.76 \\
\hline Tax avoidance & 174 & 0.03 & 0.96 & 0.28 & 0.14 \\
\hline Source: Results of data processing. & & & &
\end{tabular}

Based on the results of the descriptive statistical testing output with SPSS Version 23 in Table 4 it can be seen that:

(a) Variable tax avoidance is measured using the CETR formula. The results of the analysis using descriptive statistics on $Y$ shows the minimum value of 0.03 maximum value of 0.96 with an average of 0.2762 and a standard deviation of 0.14200

(b) Variable profitability is measured based on the amount of ROA owned by the company. The results of the analysis using descriptive statistics The profitability variable shows a minimum value of 0.07 , a maximum value of 120.8 with an average of 10.7617 and a standard deviation of 14.35167 .

(c) Variable company size is measured using the total asset formula. The results of the analysis using descriptive statistics on the size of the company showed a minimum value of 21.46 maximum value of 33.00 with an average of 28.1058 and a standard deviation of 1.75905 . 


\subsection{Classical assumption test results}

(a) Multicollinearity Test Results

Multicollinearity test aims to test whether the regression model found correlation between independent variables. A good regression model is a regression that does not show a strong correlation between the independent variables. Multicollinearity test is done by looking at the tolerance value and VIF value. If the nial tolerance is not close to 1 or less than 0.01 and the VIF value is above 10 then there is multicollinearity as well as vice versa. Test results are presented in Table 10

TABLE 2: Multicollinearity test results.

\begin{tabular}{|c|c|c|c|c|c|}
\hline \multirow[t]{2}{*}{ Model } & \multirow{2}{*}{$\begin{array}{l}\text { Correlation } \\
\text { Zero-order }\end{array}$} & \multirow[b]{2}{*}{ Partial } & \multirow[b]{2}{*}{ Part } & \multicolumn{2}{|c|}{ Collinearities statistics } \\
\hline & & & & Tolerance & VIF \\
\hline Profitability & -0.196 & -0.189 & -0.188 & 0.994 & 1.007 \\
\hline Size companies & -0.111 & -0.097 & -0.096 & 0.994 & 1.007 \\
\hline
\end{tabular}

In the table above as a result of the linear regression test, the VIF value is less than 10 , that is 1.007 and the Tolerance value is more than 0.01 , that is 0.994 , it can be concluded that there is no multicollinearity.

(b) Heteroscedasticity test

Heteroscedasticity test aims to test whether in the regression model there is a residual variance inequality one observation to another observation. If the residual variance from one observation to another observation remains, then it is called homokedastisitas and different is called heteroscedasticity. Heteroscedasticity test can be done by looking at the significant value, if the significant value is less than 0.05 the conclusion is that heteroskedasticities occur and if the significant value is greater than 0.05 , then the conclusion is not heteroscedasticity. A good regression model should not occur heteroscedasticity. The heteroscedasticity test results can be presented in table 11 below:

TABLE 3: Heteroscedasticity test results.

\begin{tabular}{|l|c|c|c|c|c|}
\hline Model & \multicolumn{2}{|c|}{ Unstandardized } & Standardized & t & Sig. \\
\hline & B & Std. Error & Beta & & \\
\hline Profitability & -0.001 & 0.001 & -0.088 & -1.187 & 0.237 \\
\hline Size & -0.015 & 0.005 & -0.228 & -3.073 & 0.002 \\
\hline companies & & & & & \\
\hline
\end{tabular}


Based on the above output it is known that the significant value of the profitability variable is 0.237 greater than 0.05 , meaning that there is no heteroscedasticity in the profitability variable. Meanwhile, it is known that the significant value of the company size variable is 0.002 which is smaller than 0.05 , meaning that there is heteroscedasticity in the firm size variable.

The conclusion of the multicollinearity test and heteroscedasticity test can be presented in the following table:

TABLE 4: Conclusions of the classical assumption test.

\begin{tabular}{l|l|l|l} 
Test & Analyst & Result & Conclusion \\
Multicollinearity & $\begin{array}{l}\text { VIF }>10 \text { and tolerance } \\
<0.01\end{array}$ & $\begin{array}{l}\text { VIF }=1.007, \text { Tolerance } \\
=0.994\end{array}$ & $\begin{array}{l}\text { There is no } \\
\text { multicollinearity }\end{array}$ \\
\hline Heteroscedasticity & significant $<0.05$ & $\mathrm{X}_{1}=0.013, \mathrm{X}_{2}=0.200$ & $\begin{array}{l}\mathrm{X}_{1}=\text { There is no } \\
\text { heteroscedasticity } \\
\mathrm{X}_{2}=\text { There is } \\
\text { heteroscedasticity }\end{array}$ \\
& & &
\end{tabular}

\subsection{Hypothesis test}

(a) Simultaneous Significance Test (Test Statistics F)

$F$ test in principle aims to determine the effect of two or more (independent variables) simultaneously on the dependent variable. The basis for decision-making in the $\mathrm{F}$ test is based on the significance value of the SPSS output, that is, if the significant variable is $<0.05$, the independent variable simultaneously has a significant effect on the dependent variable. If the significant value $>0.05$, the independent variable simultaneously does not have a significant effect on the dependent variable. $\mathrm{F}$ test results can be presented in the following table 13:

TABLE 5: Test Results $f$.

\begin{tabular}{|c|c|c|c|c|c|}
\hline Model & Sum & DF & Mean & $\mathbf{F}$ & Sig. \\
\hline Regression & & & & 4.274 & 0.015 \\
\hline Residual & 3,322 & 171 & 0.019 & & \\
\hline Total & 3,488 & 173 & & & \\
\hline
\end{tabular}

From the ANOVA test or F-test, it is obtained f count value of 4.274 with sig value. 0.015 this indicates that 0.015 is smaller than $0.05(5 \%)$ then $\mathrm{HO}$ is rejected. This means that the profitability and size of the company affect simulant to tax avoidance.

b. Partial Test (Test Statistics $t$ ) 
Statistical Test partial $t$ in multiple regression analysis aims to determine whether the dependent variable partially has a significant effect on the independent variable. The basis of decision-making $t$-test is if the significance value $<0.05$, the dependent variable has a significant effect on the independent variable. If the significant value is $>0.05$, the dependent variable has no significant effect on the independent variable. The results of the $t$-test can be presented in the following table:

TABLE 6: Test results $t$.

\begin{tabular}{l|c|c|c|c|c|}
\hline Model & \multicolumn{2}{|c|}{ Unstandardized } & Standardized & T & Sig. \\
\hline & B & Std. Error & Beta & & \\
\hline Profitability & 0.002 & 0.001 & -0.188 & -2.515 & 0.013 \\
\hline Size companies & -0.008 & 0.006 & -0.096 & -1.286 & 0.200 \\
\hline
\end{tabular}

Based on the two independent variables entered into the regression model, the variables of profitability and firm size, only one variable has a significant effect, namely the profitability variable of 0.013 , which means less than 0.05 , while the variable size of the company cannot be said to be significant because 0.200 far from 0.05 or greater than 0.05. Therefore, it can be concluded that the tax avoidance variable is not influenced by the company size variable.

\subsection{Determination coefficient (R2)}

The determination coefficient test is done to determine the percentage of influence of all profitability variables and Company Size on tax avoidance is known from the magnitude of the coefficient of determination (Adjusted $\mathrm{R}$ square) regression equation.

TABLE 7: Determination coefficients.

\begin{tabular}{l|c|c|c|}
\hline Model & $\mathbf{R}$ & R Square & Adjusted R Square \\
\hline 1 & 0.218 & 0.48 & 0.36 \\
\hline
\end{tabular}

From the results of the SPSS output model the adjusted $\mathrm{R}$ square magnitude is 0.48 or $48 \%$, this shows that the effect of profitability and firm size is weak. The rest $100 \%-$ $48 \%=52 \%$ ) is explained by other variables outside the model.

The summary of research results can be presented in the table below: 
TABLE 8: Summary of research results.

Independent Variables
Profitability
Size company

$\begin{gathered}\text { Dependent Variable Tax } \\ \text { avoidance }\end{gathered}$
Affect
Not affect

\section{Conclusions and Recommendations}

\subsection{Conclusion}

This study examines the effect of profitability and firm size on tax avoidance in manufacturing companies listed on the Indonesia Stock Exchange. Based on the results of the testing and discussion described in the previous section, it can be concluded that:

1. Based on the results of simultaneous regression tests showed that profitability and firm size simultaneously affect the occurrence of indications of tax avoidance in manufacturing companies listed on the Indonesia Stock Exchange with a value of $\mathrm{R} \wedge 2$ with the effect of profitability and firm size of 0.48 .

2. Based on the results of the partial regression test shows that profitability affects the occurrence of indications of tax avoidance in Manufacturing companies listed on the Indonesia Stock Exchange. While the size of the company does not affect the indication of tax avoidance in manufacturing companies listed on the Indonesia Stock Exchange.

3. Based on the results of the test data shows that profitability has a dominant influence on the occurrence of indications of tax avoidance in manufacturing companies listed on the Indonesia Stock Exchange.

\subsection{Suggestions}

Based on the conclusions and limitations above, some suggestions can be given as follows:

1. To the next researcher is expected:

(a) Using objects of all companies listed on the IDX.

(b) Should consider several other variables that might affect tax avoidance such as leverage, liquidity, activity ratios and so on that were not tested in this study.

(c) Consider using measurements other than CETR such as book-tax gap. 
(d) Looking for more appropriate formulations to measure tax avoidance.

2. It is expected that companies with high profitability will still pay equal taxes so that they do not cause a decline in state revenues.

\section{References}

[1] Annisa, N. A. and Kurniasih. (2012). The effect of corporate governance on tax avoidance. Jurnal Akuntansi \& Auditing, vol. 8, no. 2, pp. 95-189.

[2] Widarjono, A. (2010). Applied Multivariate Statistical Analysis. Yogyakarta: Sekolah tinggi ilmu manajemen YKPN.

[3] Atmaja, L. S. (2008). Financial Management Theory and Practice. Andi. Yogyakarta.

[4] Brad, B., Sharon, K., and Rego, S. (2013). The separation of ownership and control and corporate tax avoidance. Journal of Financial Economics, vol. 56, pp. 228- 250.

[5] Budiman, J. and Setiyono. (2011). The effect of executive character on tax avoidance. Jurnal Dalam Sna. Akuntansi. Retrieved from: Unikal\&.Ac.Id/Makalah/092-Ppjk29.Pdf

[6] Suwito, E. and Herawati, A. (September 16-17, 2005). Analysis of the influence of company characteristics on income smoothing actions carried out by companies listed on the Indonesian Stock Exchange. Simposium Nasional Akuntansi VIII. Solo, Jakarta, pp. 136-146.

[7] Diana, S. (2013). Basic Concept of Taxation. Bandung: PT Refika Aditama.

[8] Ghozali, I. (2012). Multivariate Analysis Application with IBM SPSS Program (fifth edition). Semarang: Universitas diponegoro.

[9] Raharjaputra, H. S. (2015). Financial Management and Accounting. Jakarta: Salemba empat. Retrieved from: Http://www.Tax.Go.ld/.

[10] Pudjiastuti, H. D. (2012). The Basic of Financial Management (6th edition). Yogyakarta: Upp Stim Ykpn.

[11] Fahmi, I. (2014). Introduction to Financial Management. Bandung: Alfabeta.

[12] Weygandt, J. J., Kieso, D. E., and Kimmel, P. D. (2007). Introduction of Accounting (seventh edition). Jakarta. Salemba empat.

[13] Budiman, J. and Setiyono. (2012). The effect of executive character on tax avoidance. Simposium nasional akuntansi $X V$.

[14] Sari, K. D. (February 2013). The effect of return on asset, leverage, corporate governance, company size and fiscal loss compensation on tax avoidance. Buletin Studi Ekonomi, vol. 18, no. 1. 
[15] Tampubolon, M. P. (2013). Corporate Financial Management. Eleven New Editions. Jakarta. Raja grafindo.

[16] Mardiasmo. (2009). Taxation. Yogyakarta: Andi.

[17] Ngadiman and Puspitasari, C. (2014). The effect of leverage, institutional ownership, and company size on tax avoidance in manufacturing sector companies listed on Indonesian Stock Exchange. Jurnal Akuntansi, vol. XVIII, no. 03.

[18] Prasetya, A. O. (2013). Socialization strategy as an effort to optimize central tax revenue. Jurnal Administrasi Publik, vol. 1, no. 7.

[19] Pohan, C. A. (2013). Tax Management, Tax Planning and Business Strategies. Jakarta: PT Gramedia Pustaka Utama.

[20] Garrison, R. H., Norren, E. W., Brewer, P. C., et al. (2013). Managerial Accounting (14 editions). Jakarta: Selatan, Salemba.

[21] Suandy, E. (2006). Tax Planning. Jakarta: Salemba Empat.

[22] Riyanto, B. (2008). The Basic of State Spending (fourth editions). Yogyakarta: BPFE.

[23] Sugiono. (2014). Qualitative Quantitative research and R\&D. Bandung: Alfabeta.

[24] Sujarwoni, V. W. (2105). Business and Economic Research Methodology. Yogyakarta: Pustaka baru pers.

[25] Surbakti and Surbakti, T. A. V. (2012). The Effect of Company Characteristics and Tax Avoidance in Manufacturing Industry Companies Listed on the Indonesian Stock Exchange in 2008-2010. Skripsi Universitas Indonesia.

[26] Suryana, A. B. (2013). Darn Global Corporate Taxes. Retrieved from: http://Www. Pajak.Go.Id/Content/Article/Menisik-Pajak-Perusahaan-Global

[27] Harisson, W. T., Jr., Horngren, C. T., Thomas, C. W., et al. (2012). Financial Accounting, vol. 1 (eighth edition). Jakarta: Erlangga.

[28] Waluyo. (2010). Indonesian Taxation. Jakarta: Salemba Empat.

[29] Agusti, W. Y. (2014). The Effect of profitability, leverage, and corporate governance on tax avoidance. Thesis, S1 fakultas ekonomi, Universitas Negeri Padang. 